\title{
ETHNOECOLOGY OF Mussismilia braziliensis (Verrill 1868) IN THE MUNICIPALITY OF CARAVELAS, BAHIA, BRAZIL.
}

\author{
Etnoecologia da Mussismilia braziliensis (Verrill 1868) no município de Caravelas, \\ Bahia, Brasil.
}

Alexsandro Santos da SILVA ${ }^{1 *}$; Juzenilda Gomes FIGUERÊDO ${ }^{1}$; Alexandre SCHIAVETTI ${ }^{2}$

\begin{abstract}
${ }^{1}$ Programa de Pós Graduação em Biociências e Biodiversidade: Ecologia e Conservação Ambiental, Departamento de Educação, Universidade do Estado da Bahia, Av. Kaikan, S/N - Kaikan, Teixeira de Freitas - BA, Brasil, ${ }^{2}$ Laboratório de Etnoconservação e Áreas Protegidas (LECAP) Departamento de Ciências Agrárias e Ambientais Universidade Estadual Santa Cruz.*lex-1alex@hotmail.com
\end{abstract}

Submitted: 23/10/2020; Accepted: 19/12/2020; Published: 18/02/2021

\begin{abstract}
This work is the first record of the perception of artisanal fishers in the Caravela city- Bahia and its respective districts (Ponta de Areia and Barra de Caravelas) regarding the species Mussismilia braziliensis (Verrill 1868), its ethnozoological aspects and its socio-environmental importance. The main objective is to associate the knowledge of these artisanal fishers about this species with the ethnoconservation of the Abrolhos Marine National Park (PARNAM-Abrolhos). Data collection was conducted from March to August 2019 through semi-structured interviews with 14 fishers, both men and women, from each fishing communities (Caravelas, Ponta de Areia and Barra de Caravelas). Of the 42 interviewed fishers, half are diving fishers and half fish using other methods. An ethno-mapping was carried out with two focal groups in order to know if the fishing grounds have received their names due to the presence or absence of corals. Using morphological characteristics, the focus species is grouped together with other corals belonging to different families, which are all considered to be brain corals. Other studies are recommended to appreciate the knowledge of the Caravelas fishers and use it for future environmental education, management and conservation projects of the PARNAM-Abrolhos.
\end{abstract}

KEYWORDS: Brain coral, Fishers, Conservation.

\section{RESUMO}

O trabalho se constitui no primeiro registro da percepção dos pescadores artesanais da cidade de Caravelas - Bahia e em seus respectivos distritos (Ponta de Areia e Barra de Caravelas), acerca da espécie Mussismilia braziliensis (Verrill 1868),, os aspectos etnozoológicos e sua importância socioambiental. O objetivo principal foi relacionar o conhecimento destes pescadores artesanais sobre esta espécie com a etnoconservação do Parque Nacional Marinho dos Abrolhos (PARNAMAbrolhos). A coleta de dados foi realizada de março a agosto de 2019 por meio de entrevistas semiestruturadas com 14 pescadores, homens e mulheres, de cada comunidade pesqueira (Caravelas, Ponta de Areia e Barra de Caravelas). Dos 42 entrevistados, metade são pescadores de mergulho e metade pesca usando outros métodos. Foi feito um etnomapeamento com dois grupos focais com intuito de saber se os pesqueiros têm tais nomes devido à presença ou ausência de corais. Por características morfológicas, a espécie foco do estudo é agrupada juntamente com outros corais pertencentes a diferentes famílias, sendo consideradas todas como corais cérebros. Recomenda-se novos trabalhos que valorizem o conhecimento dos pescadores de Caravelas e o utilizem para futuros projetos de educação ambiental, manejo e conservação do PARNAM-Abrolhos.

PALAVRAS-CHAVE: Coral cérebro, Pescadores, Conservação 


\section{INTRODUCTION}

Fishing communities and artisanal fishers have daily contact with the marine ecosystem. As such, they have knowledge about the biology and ecology of aquatic environments (MOURÃO and NORDI, 2003); knowledge that deals with the behavior, reproduction, feeding patterns, taxonomy and ecology of the fauna, and which can assist in the conservation and use of fishing resources (SILVA and BRAGA, 2016).

Ethnoecology is a part of ethnobiology, which studies the knowledge, emotions and way of life involving human beings and other beings that make up the ecosystem (MARQUES, 2001). Several ethnoecological studies have revealed the wealth of knowledge of artisanal fishers in Brazil as a whole and in Bahia State in particular. For example, Martins et al. (2011) studied the connections between fishers and octopuses in Coroa Vermelha (Bahia); Magalhães et al. (2012) studied ecological and biological aspects of crustaceans in northern Bahia; and Braga and Schiavetti (2013) studied the ecological knowledge of fishers from Ilhéus about turtles.

Up to date, there is no record in the scientific literature of ethnoecological studies with corals, particularly those endemic to the Abrolhos bank. The species under study is a Brain Coral known as Mussismilia braziliensis (VERRILL, 1868). It is endemic to the Abrolhos Bank and is the main species of reef-building coral in this region (CAPARELLI, 2004). Due to several events threatening corals, M. braziliensis has been placed in the vulnerable category (VU) in the Red List of Brazilian Fauna (ICMBIO, 2018) and in the Red List of Fauna of the state of Bahia (LISTA VERMELHA BAHIA, 2019).

Coral reefs cover about $0.2 \%$ of the oceans' area, but despite their small territorial expanse, they are the most productive coastal marine ecosystems with about $25 \%$ of marine species (KIKUCHI et al., 2003), and their ecological, social and economic importance is unquestionable (MMA, 2019).

The study of the relationship between fishers and the coral reefs provides a source of knowledge that is of great importance for a better understanding of these environments. It may provide tools for future Environmental Education projects by seeking to understand, clarify and raise the awareness of fishers, tourists and others who enjoy coral reefs about the importance of environmental preservation and conservation, especially concerning the endemic species existing in the Conservation Unit.

This work, carried out with artisanal fishers from a southern coastal area from Bahia, is the first record of the empirical knowledge about the species M. braziliensis as well as its ethnozoological aspects and its socio-environmental importance. 


\section{MATERIAL AND METHODS}

\subsection{Study Area}

This study was carried out in the extreme south of Bahia in the municipality of Caravelas and its districts Ponta de Areia and Barra de Caravelas. This municipality (Figure 1 ) is located at the coordinates $\left(17^{\circ} 43^{\prime} 55^{\prime \prime} \mathrm{S}, 39^{\circ} 15^{\prime} 57^{\prime \prime} \mathrm{W}\right)$ in the Abrolhos region, an area with a great wealth of coral reefs in the South Atlantic (LEÃO and KIKUCHI, 2001; DUTRA et al., 2006; VIANA et al., 2015).

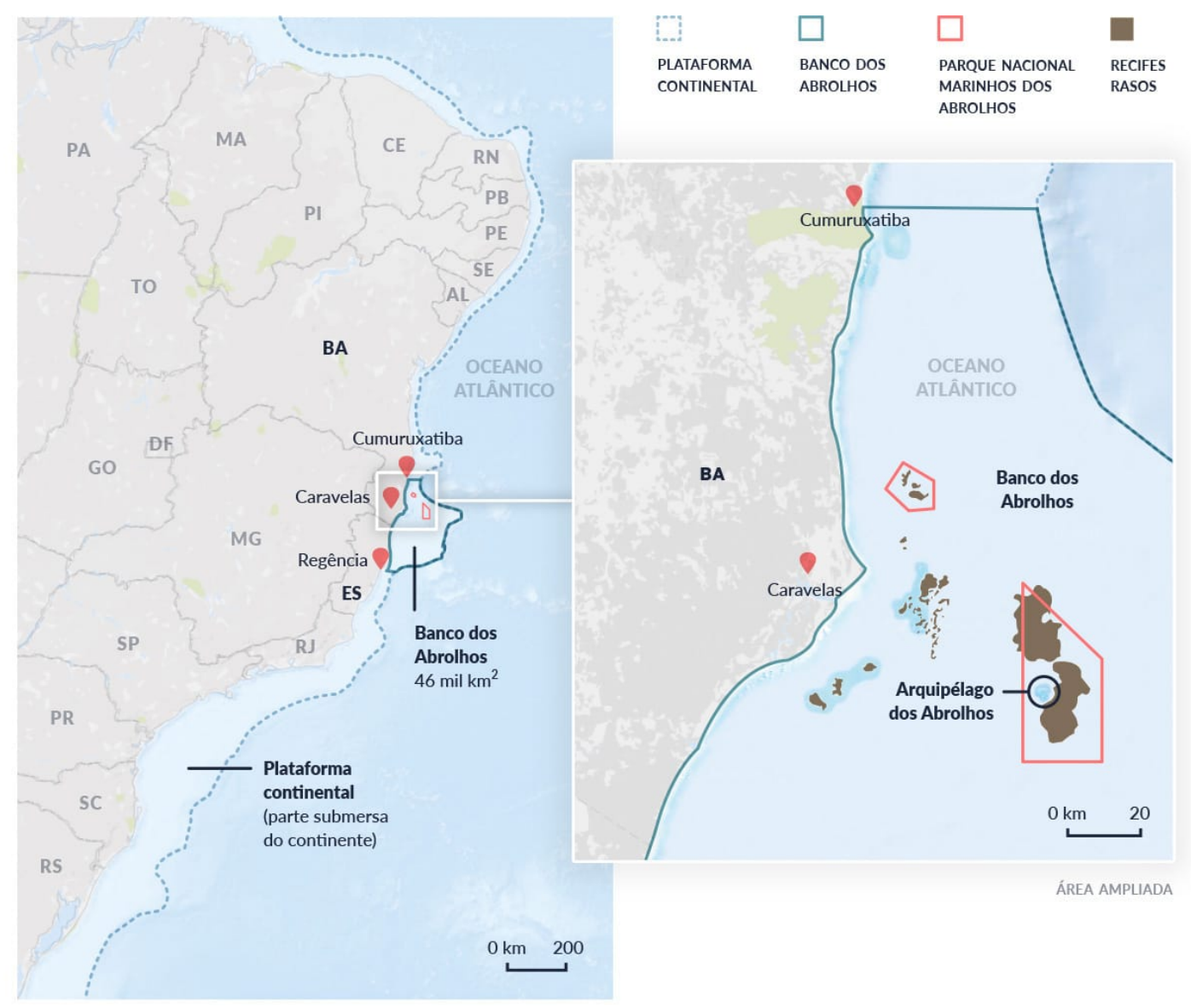

Figure 1 Study area location, Bank Abrolhos. Source: Escobar H (2016).

\subsection{Data Collection}

Data collection was conducted from March to August 2019 through semi-structured interviews with 14 fishers, both men and women, from each fishing communities (Caravelas, Ponta de Areia and Barra de Caravelas). Of the 42 interviewed fishers, half are diving fishers and half fish using other methods.

Photographs of different coral species, including that of M. braziliensis (Figure 2) and hydrocoral species, all of them endemic in Brazil, were presented to the three fishing communities of the region. Some photographs were taken from the Cifonauta Marine Biology Image Bank (http://cifonauta.cebimar.usp.br), and others were provided by Lucas 
Cabral Lage Ferreira, an oceanographer with a scholarship from the Abrolhos National Marine Park.

The Abrolhos Marine National Park, created in 1983, is an Integral Protection Conservation Unit (Unidade de Conservação de Proteção Integral) managed by the Chico Mendes Institute of Biodiversity Conservation (Instituto Chico Mendes de Conservação da Biodiversidade - ICMBIO). The region has the largest marine biodiversity in the South Atlantic, covering an area of about 91.3 thousand hectares (ICMBIO, 2014) and being contained by an area known as the Abrolhos Bank (Banco dos Abrolhos).

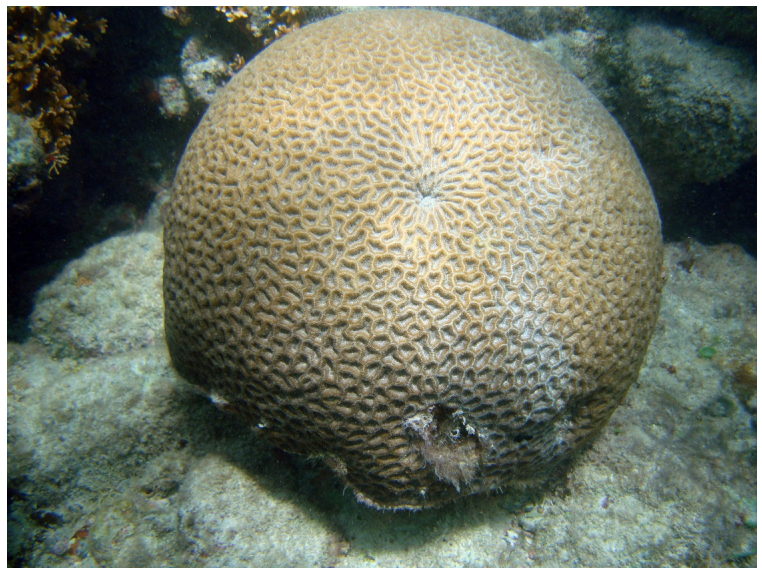

Figure 1. Brain Coral, Mussimilia braziliensis. Source: Lucas Cabral Lage Ferreira.

The interviews were always preceded by the reading of the Free and Informed Consent Term, following the guidance of the Committee of Ethics in Research (CEPUNEB), approved under the number 3.194.350.

Data analysis comprised a model combining several individual abilities. This method has been used in several Brazilian ethno-scientific researches, such as Costa-Neto (2000), Alarcon and Schiavetti (2005), Azevedo-Santos et al. (2010), Amaral (2015), and Amaral (2018).

The data were obtained and analyzed through an emic/etic approach, which compares the traditional/emic knowledge with the one from the academic/etic literature (FELEPPA, 1986 apud CASAL et al., 2011).

Berlin's (1992) principles of nomenclature and categorization were applied to the classification of the species $M$. braziliensis, namely: kingdom, life form, intermediate, generic, specific and variety, thus seeking to compare these criteria with those recorded in the literature, in addition to confirming the names assigned to the obtained categories.

Two focal groups were assembled after collecting and analyzing the data, one group composed of three fishers who dive for their catch and the other with four fishers who do 
not dive, in order to develop the ethno-maps of the fishing grounds cited by them, seeking to know if there is a relationship between the names of the fishing grounds and the presence of corals.

The identification of the species was made by the oceanographer Lucas Cabral Lage Ferreira. The abbreviations "PB-M, PC-M, PPA-M, PB-OA, PC-OA, PPA-OA" found in the text are the Portuguese abbreviations for Barra Fisherman - Diving (Pescador da Barra - Mergulho), Caravelas Fisherman, Diving (Pescador de Caravelas - Mergulho), Ponta de Areia Fisherman - Diving (Pescador de Ponta de Areia - Mergulho), Barra Fisherman Other Fishing Modalities (Pescador da Barra - Outra Arte de Pesca), Caravelas Fisherman - Other Fishing Modalities (Pescador de Caravelas -Outra Arte de Pesca), Ponta de Areia Fisherman - Other Fishing Modalities (Pescador de Ponta de Areia - Outra Arte de Pesca). They are followed by the time of fishing experience and the abbreviations "G1 and G2", which correspond to Focal Group 1 (fishers who dive) and Focal Group 2 (fishers using other modalities), respectively.

In this paper, the analyzed, described and discussed ethno-classification data represents a sub-sample of the total interviews, which included the most-frequently cited groupings by the fishers in each community, using the first four grouped species closest to the coral that is the focus of this study.

\section{RESULTS AND DISCUSSION}

Among the 42 interviewees, 40 were men and 2 were women. They were between 18 and 60 years of age, with a schooling level ranging from basic to college level and a professional fishing experience ranging from 2 to 40 years.

When the interviewees were confronted with the picture of the mushroom-shaped coral pinnacle or chapeirão (Figure 3) with the brain coral at the top to see if they knew what the image represented, they already answered what made it, without indicating a distinction between the formation and the coral, which has different names like: chapeirão, coral, coral head (cabeço-de-corais), stone head (cabeço-de-pedra), reefs, coral reefs, brain coral, great star coral (coral-jaca).

As for the fishers' knowledge on what forms the chapeirões, $100 \%$ of the interviewees recognized that it is a coral. Within the diving fishers category, $85.71 \%$ of fishers from Barra de Caravelas, $100 \%$ of fishers from Caravelas, and $85.71 \%$ of fishers from Ponta de Areia cited the brain coral or the scientific name M. braziliensis itself. The respective percentages in the category of fishers using other fishing modalities were $28.57 \%$ 
SILVA et al. Ethnoecology of Mussismilia braziliensis (Verrill 1868) in the municipality of Caravelas, Bahia, Brazil. Ethnoscientia, v.7, n.1, 2021. D.O.I.: 10.22276/ethnoscientia.v6i1.365.

for fishers from Barra de Caravelas, 28.57\% for fishers from Caravelas, and $28.57 \%$ for fishers from Ponta de Areia.

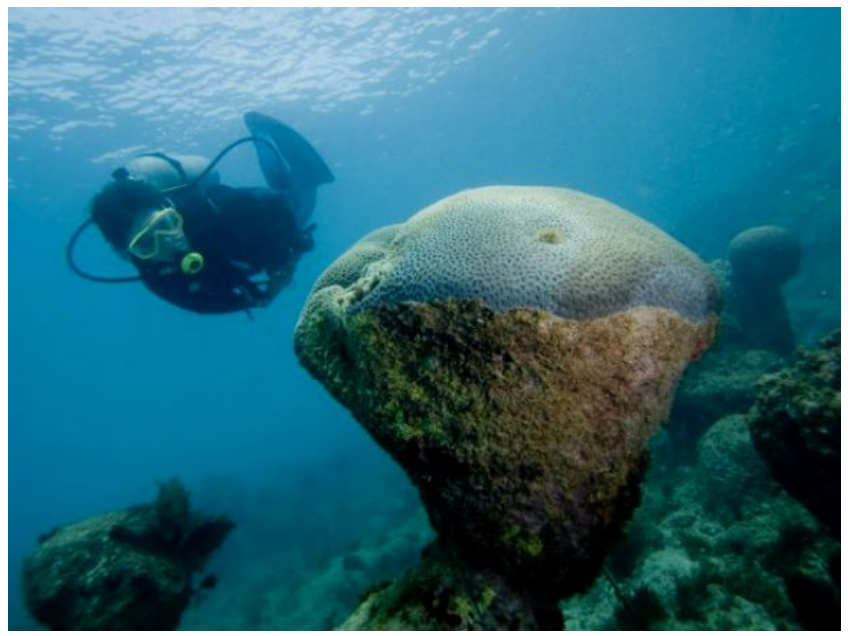

Figure 2 Chapeirão (Mussimilia braziliensis). Source: Cultura Mix.com

\begin{abstract}
It is the brain coral endemic of the region, it's only found here, in the extreme south of Bahia, it stays more on top, right, when we stay more on the surface, diving right, we, the apnea, the catch, we stay more on the surface and see the fish and go down, then, we see more of these points, you see one here, another one here below, generally it stays more on top looking for sun, the Mussismilia braziliensis (PB-M, 9 years).

Man, this is a brain coral, we fisherman here call it the cabeço, cabeço formation (PPA-OA, 14 years).

Brain coral, right? It's very similar (PC-M, 20 years).
\end{abstract}

As for the perception of the coral being a living organism, $100 \%$ of the interviewees affirmed that it is alive. Most of them know this because of the growth of the coral, as can be seen in the following passages:

\footnotetext{
Yes, first because it is a living being, because it is not stagnant like a rock, it grows, it keeps increasing and the fish make use of it in some way, I don't know how to explain it right, but I think so, certainly (PC-M, 15 years).

That then is a living being because it grows, I can't tell you its entire cycle, right? But every year it grows around $1 \mathrm{~cm}$ and $1 \mathrm{~cm}$ and a half (PB-M, 9 years).

Yes...it grows, it grows a lot (PPA-OA, 35 years).
}

Little knowledge was obtained in the three communities about the reproduction of the coral. A probable explanation for this is the main objective of the fishers, which is to go in search of fish: "Man... At the moment I don't know the answer. I have to study more about this, my thing is shrimp, really" (PB-OA, 37 years). The reproduction of the corals that was cited by the surveyed fishers are represented in the following statements:

I've seen it in videos, it releases eggs, right? (PPA -M,6 years)

So they say, right? People say that it proliferates, right? one year, ah...in the moon period, it releases its little egg, at night, it reproduces only at night, right? To spread itself around, right? ...of the chapeirão, the chapeirão is not only one species, but it's actually several species of coral, one on top of the other, next to each other (PB-M, 9 years). 
SILVA et al. Ethnoecology of Mussismilia braziliensis (Verrill 1868) in the municipality of Caravelas, Bahia, Brazil. Ethnoscientia, v.7, n.1, 2021. D.O.I.: 10.22276/ethnoscientia.v6i1.365.

I've heard it said, understand? It's, like ... it spawns, it releases its eggs, understand? It's a phase of the moon there, then the current takes it, I don't know much about it though (PC-OA, 6 years)

Yes. And I don't know about the period, but I think it's according to moon and tide (PB -OA, 18 years).

If it has its germination, it must spread well through the sea current itself, it spreads its germination and then certain chapeirões, right? With time they take shape like a... we learned a little from what the projeto coral vivo taught us (PPA -M, 13 years)

M. braziliensis is hermaphrodite and spawns gametes (CAPARELLI, 2004; SILVA and FIGUERÊDO, 2020). Its spawning presumably occurs between March and mid-May (PIRES et al., 1999; CAPARELLI, 2004), and the release of gametes occurs near the new moon (PIRES et al., 2016). According to these authors, the gametes separate and spread by the water current. After a while the cross-fertilization is initiated, where the ovocyte of one colony is fertilized by the sperm of another colony.

Coral reefs provide ecosystemic goods and services to society, including food, tourism, storm protection and nurseries for species of commercial interest (BURKE et al., 2011). The important functions of brain corals are highlighted by the interviewees, such as the maintenance of ecological balance, the ecological relationship with different organisms, shelter for fish, indicators of environmental health, and natural physical barriers.

Wealth of the sea, controlling the $\mathrm{pH}$ of the water, in addition to the appearance, right, man? Everything very colorful and such, a source of ...how do you say? A sample of the environment, if the coral is sick, the environment is sick. They suffer with these things like global warming, pollution, it is an indication, is the environment healthy, is the environment sick? (PC-M, 20 years)

Corals form a big wall, which prevents the big waves from reaching the shore, understand? It serves as a barrier, so much so that when you're at sea, and you catch bad weather there at sea, we go inside the coral, to be able to get flat seas there, to be able to shelter, shelter from the storm, so the storm hits outside and comes breaking, breaking, when it arrives, a boat arrives here and it is real calm, so it's a kind of shelter for us too (PC-M, 20 years)

Depending on the size of the colony, it serves as a shelter for fish, for hiding, for all that, and I believe that it can be used for this, just so you see, if another one had formed on its side, they would form the caves so that the fish could hide, escape from predators.... (PPA- M, 20 years)

Of the 18 species of coral existing in Brazil, 8 of them are endemic, with emphasis on the reef-building coral-brain species M. braziliensis (ICMBIO, 2018). As Sabadini (2017) says, the high endemism of reef-building corals increases their relevant importance 
for the Brazilian coast. In the three communities, 35.71\% of the fishers cited some species of the types of corals that exist, while $64.28 \%$ did not know or remember the names.

From the brain coral Mussismilia harti, and Mussismilia braziliensis,.. there is the coral mole, casca de jaca, Millepora which is the fire coral, which is better known, palmas which is a gorgonia, rabo de macaco, there are anemones, among other things (PB-M, 9 years).

It is worth stressing that of the fishers who mentioned the types of corals that exist, $73.33 \%$ were diving fishers. Those fishers using other fishing modalities mentioned these types less $(26.66 \%$ ), since it is not directly part of their visual field (This is more for those who dive, right? They are the ones who understand these things. Now, for those who don't dive...I'm more on the top of the water, on top of the water I know how to explain something, but down there) (PB-OA, 18 years).

Some fishers have already participated in lectures offered by ICMBIO and the Coral Vivo project. Others practice recreational diving besides the spear fishing. And some have this knowledge because of older fishers who have transmitted this knowledge.

There is the fire coral, there is that branch, if you put it in your mouth you won't be able to stand it, it's worse than pepper, it burns your entire mouth, there are several types of coral, I always, I use it more as I learned from the old fishermen, but if it's scientific I don't know (PB-OA, 34 years)

Many of the interviewees reported the existence of ecological relations between the brain coral and fish, in addition to quotes that demonstrate interactions with other individuals, such as interactions of the coral with humans, with algae and with crustaceans. And these relationships can be classified as harmonious (without damage) or inharmonious (with damage) (Figure 4).

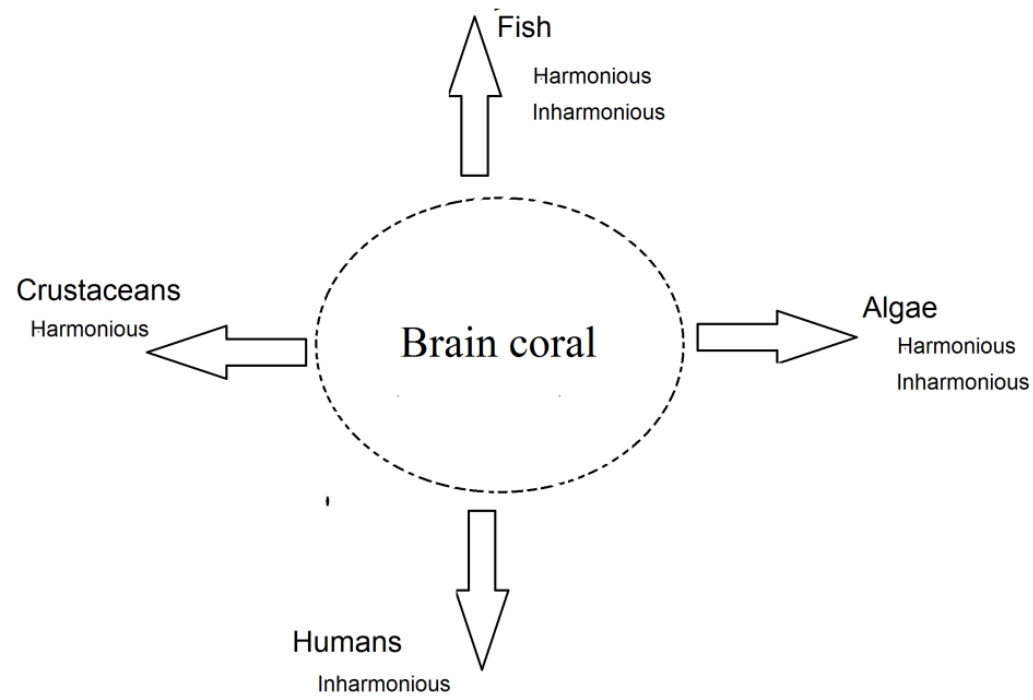

Figure 3. Ecological relations between the corals and other organisms, according to the fishers. Source: Authors. 
The herbivory displayed by fish is a key factor in reefs, for it controls the algae biomass over the corals (MCCOOK et al., 2001; SILVA, 2010), since both compete for space to survive (FEITOSA, 2014).

He is the top of a chain, because usually the parrot fish, besides others, but the Parrot fish right, because they feed on the algae that grow on it, it is a real gardener, the Parrot fish, a reef cleaner (PB-M, 9 years)

The predation of corals by fish is done in two ways: through focused bites, where the individual bites in a single area repeatedly; or through shallow bites distributed throughout the colony (BRUCKNER and SOLLINS, 2000; FEITOSA, 2014). This relationship was observed by fishers with different types of fish.

The friar eats it, there is also the boxfish that eats it, the Budião, the much talked about parrot. (PC-OA 20 years)

Recently, a video was recorded with the first evidence of the existence of the Lionfish (Ptoris spp ) in Bahia State. The video is low resolution, however, and after being analyzed by several experts it has been considered to be fake (UFPE, 2018). According to the Head of the Abrolhos Marine National Park, a monitoring with researchers, monitors and other professionals of this Conservation Unit was started to verify the veracity of the information considering the gravity of this fact (ICMBIO, 2018).

Man, there is a fish called eee...lion fish or tiger fish, lion fish which is coming
from Africa, it came, came and stayed in, in...in Espirito Santo it has already been
found, it wipes out certain species of corals and fish too (PPA-OA, 14 years).

Even though the presence of the Lionfish at the Abrolhos Bank is considered false, constant monitoring is necessary, since this species has already been sighted in other Brazilian aquatic environments, such as Arraial do Cabo in the Rio de Janeiro Lakes region. It is an invasive reef species in the Atlantic Ocean and may disturb the food chain of the environments it invades (ICMBIO, 2018).

When asked what purposes the coral serves, one of the fishers reported that individuals belonging to the crustacean class are protected by the coral ("Protecting the fish, is ...protecting the lobsters" PC - OA, 25 years). According to Moreira (2008), coral reefs shelter several species of fish, mollusks, crustaceans, cnidarians and algae, in addition to several other living beings.

No studies have been found reporting the existence of sun coral at the Abrolhos Bank, but studies show that two species of the genus Tubastraea, native to the Pacific Ocean, have been reported in Brazil since 1980 in the state of Rio de Janeiro, causing 
serious ecological, economic, and social impacts on the environment (OIGMAN-PSZCZOL et al., 2017), and they are reason for concern for the fishers in the three Caravelas communities.

We have to be very careful with the sun coral that is very close to us, it kills all the other corals (PC-M, 36 years)

Coral reefs are threatened by several factors that can lead to coral death. These factors are reported by Leão (1994) as natural and anthropogenic agents. The interviewees are well aware of the reasons that may lead to the death of corals and what the individuals of these species become when they die. Among the impacts cited, the increase in water temperature $(21 \%)$ is the most reported by interviewees who dive to fish, and the use of nets $(22 \%)$ on the reefs is the most cited by fishers using other fishing modalities because pieces of coral end up being caught in the nets.

The impacts cited by fishers may (e.g. trampling and use of nets) or may not (e.g. water temperature and oil spills) be connected to the fishing activity, as we can see in figure 5.

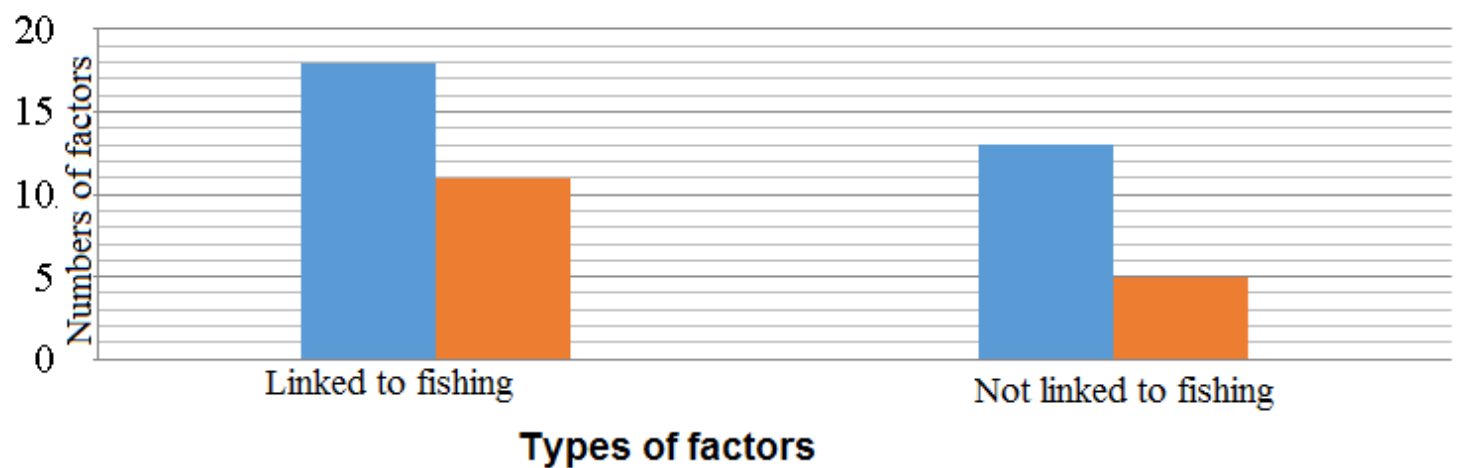

- Fishermen who dive $\quad$ Fishermen using other modalities

Figure 4. Numbers of factors that enable coral death informed by the fishers of the Municipality of Caravelas (County seat, Ponta de Areia and Barra de Caravelas) in the region of the Abrolhos National Marine Park in 2019, N 21 (diving fishers) and N 21 (other fishing modalities). Source: Authors.

According to Greenpeace (2019), coral reefs are currently being threatened due to an authorization given by the president of the Brazilian Institute of Environment and Renewable Natural Resources (Instituto Brasileiro do Meio Ambiente e dos Recursos Naturais Renováveis, IBAMA) to hold an auction of the oil and natural gas blocks at the Abrolhos bank. This auction is one of the concerns of the Caravelas fishers, since many are dependent on fish for survival, and the occurrence of oil spills in the coral reefs can cause irreversible damage to the environment, affecting the source of income of the fishers. 
SILVA et al. Ethnoecology of Mussismilia braziliensis (Verrill 1868) in the municipality of Caravelas, Bahia, Brazil. Ethnoscientia, v.7, n.1, 2021. D.O.I.: 10.22276/ethnoscientia.v6i1.365.

Man's intervention can provoke if for some reason, it is...., I don't know, just like there is oil exploration here now, in our region, if they start exploring oil and there's a leak and the oil arrives here, it kills, it will kill, not only the corals, but any living being that lives there, so the great predator, in my opinion, it's the, it's actually humans, you know? (PC - M 20 years)

Another problem pointed out by the fishers is the presence of corals with the socalled bleaching phenomenon, which is caused by the exit of the zooxanthellae, photosynthetic algae that live inside the coral tissue, and this phenomenon may be related to a relatively small increase in the temperature of superficial waters (SZMANT and GASSMAN 1990, FAUTIN and BUDDEMEIER 2004; LEÃO et al., 2008).

\begin{abstract}
...we see one of these special things here captain, there are times that this animal becomes white, we see it directly, I don't know if it is the temperature of the water, if it is pollution, if it is something, see it here white... if you touch it here at the bottom, it releases a goo, it releases a gooey secretion in your hand, when it is alive, but when it is white, you pick it up here and it doesn't release anything (PPA-M, 20 years).
\end{abstract}

Many of the interviewees are aware of the damage the environment could suffer if the brain coral disappeared from the sea, and many answers are related to the fisherman's source of income, the fish. According to Moberg and Folke (1999), coral reefs provide food and are the main source of economic resources for hundreds of thousands of people living in the tropical regions of our planet. The sections below describe some of the problems if corals were to disappear from the reef environment:

\footnotetext{
... If these corals disappeared from here it would be difficult, because it is a home and food for many fish. I'm not going to say which fish will disappear together with it, but the area that has the stones will usually become a desert. (PPA-M, 23 years)

It would decrease fish reproduction, fish species (PB-M, 3 years)

It will have an impact, right? It will have some impact on the fishing grounds, that's because it's already, it's its environment, right? If it starts to leave, it will certainly do harm (PB-OA, 34 years)

We would have many problems, one of the factors is that the fish would not have their place of residence, they would lose their food because here the food is created for the fish to feed themselves, they would lose shelter, this I say for the fish (PC-M, 20 years)

Scarcity of fish species that many fishermen need for their consumption, for sales, understand? It would disappear, so they are very important in the formation of shoals (PPA-M, 13 years)

Man, then it is a great devastation in our fishing area, because without the coral there is no food, no fish, it all ends (PPA-OA, 35 years)
}

The criteria used by fishers to classify and group the corals were: shape, color, size, consistency, composition, proximity and appearance. And both within the category of diving fisherman (76.14\%) and that of fishers using other modalities (80.95\%), the shape criterion was the most used one. 
Among the 21 groups formed by the diving fishers, 10 groups were formed taking into consideration the 4 mentioned species that were closest to the species M. braziliensis, with 2 groups having the most mentions with 9.52\% each: Siderastrea stellata, $M$. braziliensis, Favia leptophylla, Mussismilia hartti, and M. hispida, and the other group with M. braziliensis, S. stellata, F. leptophylla, M. hartti, and M. hispida. Similarly, among the 21 groups of fishers using other modalities, 8 groups were formed, with 2 groups having most mentions, both with 9,52\%, namely: S. stellata, F. leptophylla, M. braziliensis, $M$. hispida, and M. hartti; the other group with M. braziliensis, F. leptophylla, S. stellata, M. hartti, and M. hispida.

Among the grouped species, the general characteristic pointed out for their recognition was Coral, being it a generic folk name. These results show that the groupings formed by the fishers include different species in the same family, as we can see in figure 6 . However, by going up a hierarchical level in the scientific taxonomy, the species are "groupable" at the Order level (Scleractinia) (LEÃO and KIKUCHI, 2001).

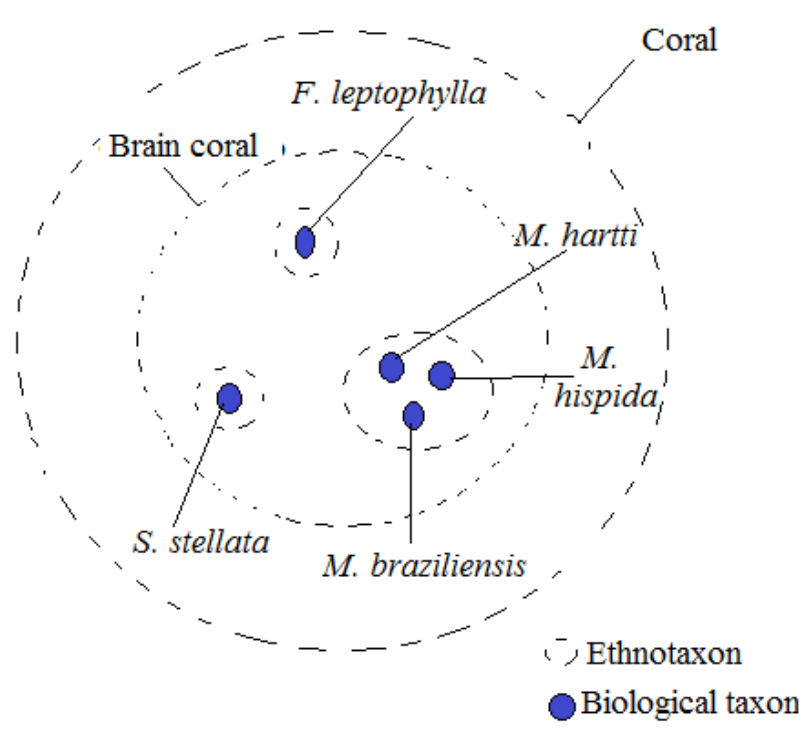

Figure 5 Specific folk names pointed out by the fishers of the Caravelas Municipality. Source: Authors.

It should be noted that the groupings formed by the fishers place the species $F$. leptophylla closer to M. braziliensis than M. hartti and M. hispida, to which it is more closely related genetically, but this result may be due to the photos chosen for this work, since they may not represent the way that fishers see the corals in their fishing areas.

As for the ethno-mapping (Figure 7), an understanding was sought for the reason of the names of the demarcated fishing grounds. With regard to the meaning of the names 
SILVA et al. Ethnoecology of Mussismilia braziliensis (Verrill 1868) in the municipality of Caravelas, Bahia, Brazil. Ethnoscientia, v.7, n.1, 2021. D.O.I.: 10.22276/ethnoscientia.v6i1.365.

(Tab. 1), the information given by the focal group of diving fishers (G1) is consistent with the other group, fishers who do not dive (G2), with differences in the points demarcated on the map.

Table 1. Names of the fishing grounds and the reasons for receiving these names according to the focal groups, G1 (fishers who dive $\mathrm{N}=3$ ) and $\mathrm{G} 2$ (fishers who do not dive $\mathrm{N}=4$ ) in the Municipality of Caravelas, Bahia State.

G 1 - Fishermen who dive G2 - Fishermen who don't dive

Recife de Areia - is more sand than coral. Recife de Areia - sand basin, sand crown.

Recife da Lixa - has a lot of sand fish, nurse Recife da Lixa-nurse shark.

sharks.

Pedra de Leste - For being exactly to the east, Pedra de Leste - Position of the wind, to the geographical point. east.

Pedra Virada - A tumbled stone, the elder say Pedra Virada - A tumbled stone. it was a stone that tumbled.

Pedra Alta - A stone that stays on the surface, Pedra Alta - A stone that stays above the that is exposed. waterline, exposed.

Sarrado - Because it is pitted on the bottom, Sarrado - Because it is separated from the you cannot see the stones, several stones parcel, it is outside the parcel.

very close together, it is a deep reef at the bottom.

Vigilante - Because of a ship called Vigilante - The vigilante and the Recife da vigilante.

It is the same as Recife de Lixa. Lixa are the same, because of a wreck of a ship called vigilante.

Recife da Lixa and Vigilante are the same fishing ground.

The ethno-mapping enabled the interaction of fishers about the location of each point on the map, generating discourses about the fishing grounds, such as where the Pedra de Leste is located. When pointing out this fishing ground, the G1 fishers had disagreements about the geographical position:

\footnotetext{
"But isn't Pedra de Leste by land? Pedra de Leste has to be by land".

"But that's right, it's going back to land, if Pedra Grande is here, Pedra Grande is outside Pedra de Leste"

"There's no way, because it's too far away, if you put it on this side".
}

According to Alvarenga (2004), the Pedra de Leste is located inside the Parcel das Paredes, and it is the fishing ground nearest to the continent, "protected from the dominant winds from the east and northeast" (LEÃO et al, 2008).

All the fishing grounds mentioned by the fishers of the focal groups are located inside the Parcel das Paredes, with the exception of Sarrado, which according to the G1 
fishers "is stone on the bottom, so it is not marked on the map, it extends beyond this parcel”. According to Leão et al., (2008), this parcel is the largest reef structure of the Abrolhos Bank, having a group of isolated reefs and so named because of the existence of abrupt walls on the leeward side of the reefs.

According to Gusmão (2015), inside the Parcel das Paredes, specifically in Lixa Reef, a ship called Vigilante bound from Rio de Janeiro was shipwrecked in 1943. This information is corroborated by both focal groups.

Besides the fishing grounds already cited by the fishers of Caravelas, Ponta de Areia and Barra de Caravelas and those demarcated on the map by Leão et al. (2003), such as Sebastião Gomes, Pedra Grande, Coroa Vermelha and Viçosa, the names of other fishing grounds came up during the ethno-mapping, such as As Pontas ("As pontas have this name because they make these points right here on Parcel das Paredes", G2), Aranguera and Pedra Nova, which are not demarcated in this work in the ethnomap for discussion.

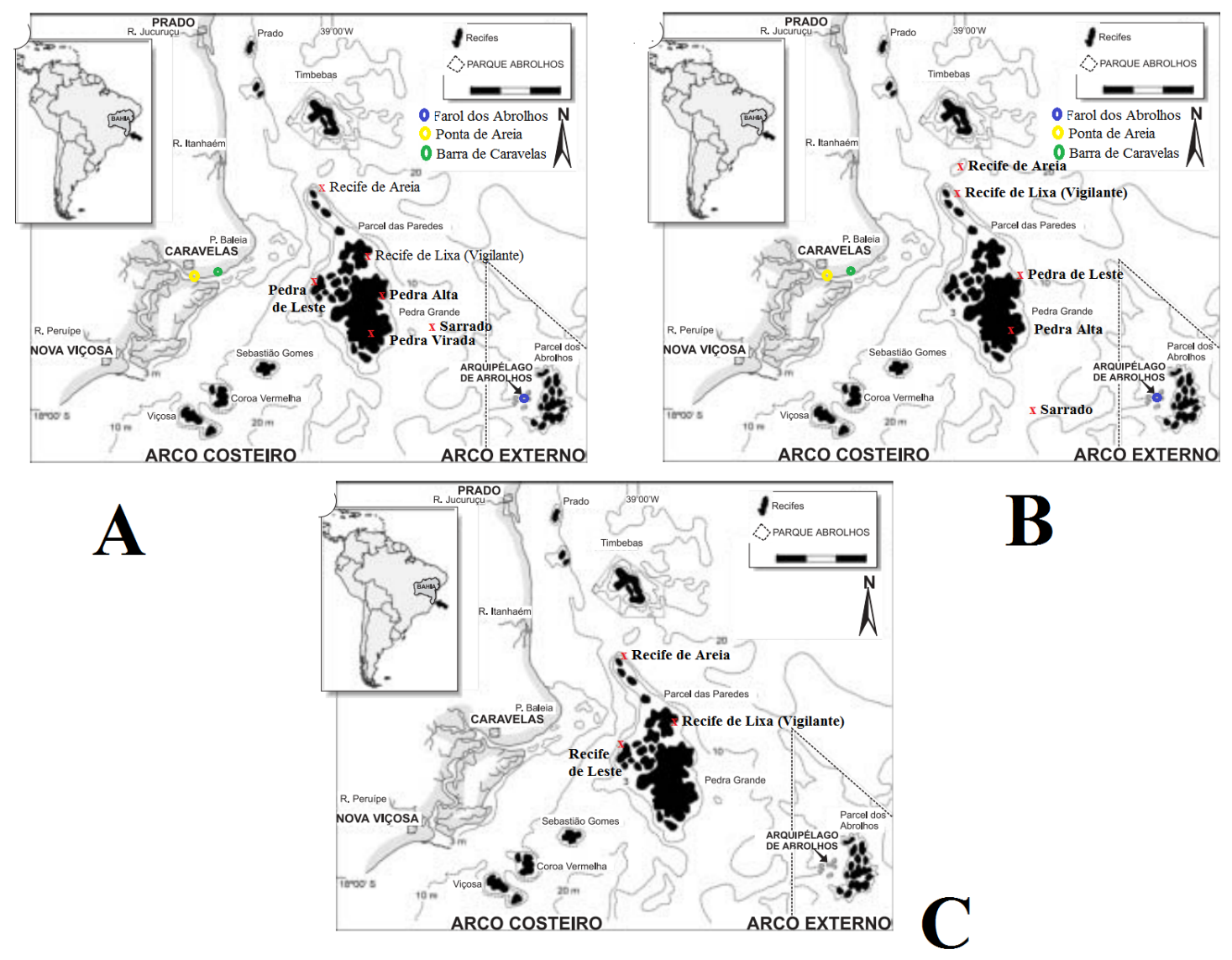

Figure 7 - Ethno-mapping G1 (A); ethno-mapping G2 (B) Fishing ground map (modified from Leão et al., 2003; Spanó, 2004; Leão and Kikuchi, 2005 ) (C).

No records of the location of the fishing grounds Pedra Alta and Pedra Virada were found in the scientific literature. According to the fishers, these fishing grounds were 
SILVA et al. Ethnoecology of Mussismilia braziliensis (Verrill 1868) in the municipality of Caravelas, Bahia, Brazil. Ethnoscientia, v.7, n.1, 2021. D.O.I.: 10.22276/ethnoscientia.v6i1.365.

subdivided to facilitate their localization: "They are glued together, all inside Parcel das Paredes" (PB-M, 9 years); "They were only divided to identify the location, but it is all within parcel" (G1).

The ethnobiological knowledge presented here is heterogeneous, but congruent with the scientific literature. This result was similar to the work done by Dócio et al. (2010), who studied the knowledge of artisanal fishers about the ecological interactions of sponges.

\section{CONCLUSIONS}

The fishers of Caravelas have extensive knowledge about the importance of the species $M$. braziliensis for the maintenance of the environmental balance, and this knowledge can be an ethnoconservation tool for the Abrolhos National Marine Park.

Considering that several problems that can cause the death of the coral are part of the fishers's daily lives, the impacts related to fishing are the main threat to the coral under study from an emic point of view, with the existing relationship between human beings and the corals being considered inharmonious by the fishers.

The recorded knowledge can be compared with future work on other fishing communities of the Abrolhos Bank to identify its importance and biological and ecological aspects, in addition to checking the taxonomy of the brain corals described by the fishers, making it possible to analyze if they are in agreement.

Based on the results obtained and morphological characteristics, the species M. braziliensis is grouped together with other corals belonging to different families, which are all considered to be brain corals. Therefore, other studies are recommended that value the knowledge of the Caravelas fishers and use it for future environmental education, management and conservation projects of PARNAM-Abrolhos.

\section{ACKNOWLEGMEMTS}

The authors would like to thank the fishers of the Caravelas city (Sede, Ponta de Areia and Barra de Caravelas) for their time and knowledge granted to the research; the oceanographer fellow Lucas Cabral Lage Ferreira of the Abrolhos National Marine Park for the identification of the corals and hydrocorals used in this work; Professor Benedito Ralile Foundation for the resources provided during the research; and finally, the volunteers and undergraduates of the Biological Sciences Course of the State University of Bahia, Fabio Teixeira Silva and Thuania Ramos Figueiredo. Thanks to the National Counsel of Technological and Scientific Development (CNPq) for productivity grant for AS. 


\section{REFERENCES}

ALARCON D.T; SCHIAVETTI, A. O Conhecimento dos pescadores artesanais de Itacaré sobre a fauna de vertebrados (não peixes) associados às atividades pesqueiras. Gerenciamento Costeiro Integrado, v. 4, p. 1, 2005.

ALVARENGA, M.F. Recrutamento de corais recifais no Banco dos Abrolhos, Brasil. Dissertação de Mestrado (Programa de Pós-Graduação em Zoologia) Museu Nacional, Universidade Federal do Rio de Janeiro, Brasil. 2004.74p.

AMARAL, M. et al. Aspectos relacionados à pesca artesanal do Rio Curiú e lago tapera, Macapá-AP. Enciclopédia Biosfera, Centro Científico Conhecer - Goiânia, v.11 n.22, p.2852-2861, 2015.

AMARAL, D.F. Etnoecologia dos pescadores artesanais de Sobradinho-BA. Dissertação de Mestrado, Universidade do Estado da Bahia, Brasil. 2018.71p.

AZEVEDO-SANTOS, V.M. et al. Concepção dos pescadores artesanais que utilizam o reservatório de Furnas, Estado de Minas Gerais, acerca dos recursos pesqueiros: um estudo etnoictiológico. Biotemas (UFSC), v. 23, p. 135-145, 2010.

BERLIN, B. Ethnobiological classification: principles of categorization of plants and animals in traditional societies. Princeton University Press, Princeton, USA, 1992, p.335.

BRAGA, F.H.; SCHIAVETTI, A. Attitudes and local ecological knowledge of experts fishers in relation to conservation and bycatch of sea turtles (reptilia: testudines), Southern Bahia, Brazil. Journal of Ethnobiology and Ethnomedicine, v. 9, p. 15, 2013.

BURKE, L. et al. Reefs at Risk Revisited. World Resources Institute, Washington, DC, 2011.

BRUCKNER, A.W.; SOLLINS, P. Parrotfish predation on live coral: 'spot biting' and 'focused biting'. Coral Reefs, v. 19, p. 50, 2000.

CASAL, F.S.; SOUTO, F.J.B. "Adonde é o aposento do pescado?" Ecozoneamento do manguezal na pesca artesanal de crustáceos da Reserva Extrativista Marinha da Baía de Iguape, Maragogipe-BA. Sitientibus Série Ciências Biológicas , v. 11, p. 143-151, 2011.

CAPARELLI, A.C.; Esforço reprodutivo de Mussismilia braziliensis (Verrill, 1868) (Cnidaria, Scleractinia, Mussidae) no complexo recifal dos Abrolhos, BA, Brasil. Dissertação de Mestrado, Universidade Federal do Rio de Janeiro, 2004.53p.

COSTA NETO, E.M.; MARQUES, J.G.W. Etnotaxonomia de recursos ictiofaunísticos pelos pescadores da comunidade de Siribinha, norte do Estado da Bahia, Brasil. Biociências, v. 8, n. 2, p. 61-76, 2000.

DOCIO, L. et al. Interações ecológicas de esponjas marinhas (Animalia, Porifera) segundo pescadores artesanais da Baía de Camamu, Bahia, Brasil. Biotema, v. 23, p.181-189, 2010. 
DUTRA, G.F. et al. A rapid marine biodiversity assessment of the Abrolhos Bank, Bahia, Brazil. RAP Bulletin of Biological Assessment 38. Conservation International, Washington, DC, USA, 2006. p. 155.

ESCOBAR, H. Recifes em risco. (2016) Disponível em: $<$ https://infograficos.estadao.com.br/especiais/recifes-em-risco/> Acesso em: 15 de Out. de 2019

FAUTIN, D.G.; BUDDEMEIER, R.W. Adaptive bleaching: a general phenomenon. Hydrobiologia v.530/531, n.1-3, p.459-467, 2004.

FEITOSA, J.L.L. Ecologia da herbivoria por peixes-papagaio no Atlântico. Tese de Doutorado, Universidade Federal de Pernambuco, Recife, Brasil, 2014. 139p.

GREENPEANCE. O petróleo ronda Abrolhos. (2019). Disponível em: $<$ https://www.greenpeace.org/brasil/blog/o-petroleo-ronda-abrolhos/> Acesso em: $15 \mathrm{de}$ agosto de 2019

GUSMÃO, D. M. Sítios Arqueológicos de naufrágios da Baía de Todos os Santos, Salvador - BA: estudo de caso do Clipper Blackadder. Dissertação (Programa de PósGraduação em Arqueologia) - Universidade Federal do Sergipe, São Cristóvão, 2015.192p.

ICMBIO - Instituto Chico Mendes de Conservação da Biodiversidade. Parque Nacional Marinho dos Abrolhos. (2014). Disponível em: <http://www.ICMBIO.gov.br >Acesso em: 26 de Ago de 2018

ICMBIO - Instituto Chico Mendes de Conservação da Biodiversidade. Livro Vermelho da Fauna Brasileira Ameaçada de Extinção. (2018). Disponível em: < http://www.ICMBIO.gov.br/portal/images/stories/comunicacao/publicacoes/publicacoesdiversas/livro_vermelho_2018_vol1.pdf<Acesso em: 20 de Set de 2019

ICMBIO - Instituto Chico Mendes de Conservação da Biodiversidade. Plano Interpretativo Parque Nacional Marinho dos Abrolhos. (2018). Disponível em: > http://www.ICMBIO.gov.br/portal/images/stories/biodiversidade/UC-

RPPN/plano_interativo_parna_marinho_dos_abrolhos_2018.pdf $<$ Acesso em: 20 de Set de 2019

ICMBIO - Instituto Chico Mendes de Conservação da Biodiversidade. Alerta: possível ocorrência do peixe-leão no Brasil. (2018). Disponível em: http://www.ICMBIO.gov.br/portal/ultimas-noticias/20-geral/9878-alerta-possivelocorrencia-do-peixe-leao-no-brasil>Acesso em: 14 de Out de 2018

LEÃO, Z.M.A.N. The coral reefs of Southern Bahia. In: B. Hetzel and CB. Castro. Corals of Southern Bahia. Nova Fronteira, Rio de Janeiro, p. 151-159, 1994.

LEÃO Z.M.A.N.; KIKUCHI, R.K.P. The Abrolhos Reefs of Brazil. In: U. Seeliger; L. D. Lacerda; B. Kjerfve. (Org.). Coastal Marine Ecossystem of Latin America. Berlin: Springer-Verlag. v.144: p. 83-96, 2001. 
LEÃO, Z.M.A.N. et al. Corals and coral reefs of Brazil. In: CORTES, E. (Ed.), Latin America Coral Reefs . Elsevier Publisher, Amsterdam, p. 9-52, 2003.

LEÃO, Z.M.A.N. et al. Branqueamento de corais nos recifes da Bahia e sua relação com eventos de anomalias térmicas nas águas superficiais do oceano. Biota Neotrop. v.8, n.3, p. 69-82, 2008. Disponível em: em: $\quad<$ http://www.biotaneotropica.org.br/v8n3/pt/abstract?article+bn00808032008. Acesso em: 22 de Ago de 2019.

LEÃO, Z.M.A.N.; KIKUCHI, R.K.P. The Abrolhos reefs of Brazil. Coastal Marine Ecosystems of Latin America, v. 144 p. 83-96, 2001.

LEÃO, Z. M. A. N.; KIKUCHI, R. K .P. A relic coral fauna threatened by global change and human activities, Eastern Brazil. Marine Pollution Bulletin, Amsterdan, v. 51, p. 599$611,2005$.

LEÃO, Z.M.A.N. et al. Os recifes de coral da APA Ponta da Baleia, Bahia. OLAM Ciência \& Tecnologia, Rio Claro, v. 8, p. 287-315, 2008.

LISTA VERMELHA BAHIA. Invertebrados Marinhos, lista de espécies com ocorrência na Bahia selecionadas para avaliação do estado de conservação. 2019. Disponível em: $\quad<$ http://www.listavermelhabahia.org.br/pdf/InvertebradosMarinhos.pdf<Acesso em: 20 de Set de 2019.

KIKUCHI, R.K.P. et al. Branqueamento de corais nos recifes da Bahia associado aos

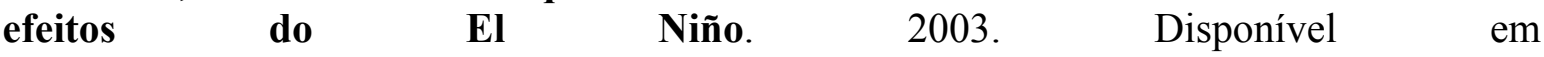
em: $<$ http://www.abequa.org.br/trabalhos/mudancas_364.pdf $>$ Acesso em: 16 de out de 2019

MAGALHÃES, H.F. et al. Local knowledge of traditional fishers on economically important crabs (Decapoda: Brachyura) in the city of Conde, Bahia State, Northeastern Brazil. Journal of Ethnobiology and Ethnomedicine, v. 8, p. 1-10, 2012

MARQUES, J.G. Pescando Pescadores. São Paulo-SP, $2^{\circ}$ edição, Editora NUPAUB-USP, 2001. p.258.

MARTINS, V.S. et al. Conexões entre pescadores e polvos na comunidade de Coroa Vermelha, Santa Cruz Cabrália, Bahia. Sitientibus Série Ciências Biológicas, v. 11, p. 121-131, 2011.

MMA - Ministério do Meio Ambiente. Recifes de corais. 2019 Disponível em: $<$ https://www.mma.gov.br/biodiversidade/biodiversidade-aquatica/zona-costeira-emarinha/recifes-de-coral>. Acesso em: 16 de agosto de 2019.

MCCOOK, L.J. Competition between coral and algal turfs along a gradient of terrestrial runoff in the nearshore central Great Barrier Reef. Coral Reefs, v.19, p. 400-417, 2001.

MOBERG, F.; FOLKE, C. Ecological goods and services of coral reef ecosystems. Ecological Economics, v.29, n.2, p.215-233, 1999. 
MOREIRA, P.D.P. Mapeamento De Habitats do Recife de Coral Pedra de Leste, Abrolhos, Utilizando Imagens Orbitais Quickbird e Landsat7 Etm+. Dissertação de Mestrado, Universidade Estadual de Santa Cruz, Ilhéus, Brasil. 2008.

MOURÃO, J.D.S.; NORDI, N. Etnoictiologia de pescadores artesanais do estuário do rio Mamanguape, Paraíba, Brasil. Boletim do Instituto de Pesca, São Paulo, v. 1, n. 29, p. 917, 2003.

OIGMAN-PSZCZOL, S. et al. O controle da invasão do coral-sol no Brasil não é uma causa perdida. Ciência e Cultura, v. 69, p. 56-59, 2017.

PIRES, D.O. et al. Reef coral reproduction in the Abrolhos Reef Complex, Brazil: the endemic genus Mussismilia. Marine Biology, v.135, n. 3, p. 463-47,1999.

PIRES, D.O. et al Reprodução de corais de águas rasas do Brasil. In: Zilberberg C, Abrantes DP, Marques JÁ, Machado LF, Marangoni LFB. (Org.). Conhecendo os Recifes Brasileiros: Rede de Pesquisas Coral Vivo. 1ed. Rio de Janeiro: Série Livros Museu Nacional, v. 58, p. 111-128, 2016.

SABADINI, S.D.C. Suscetibilidade dos recifes de Abrolhos aos eventos de branqueamento de corais. Dissertação de Mestrado, Universidade Federal de Minas Gerais, Belo Horizonte, Brasil. 2017. 89p.

SILVA, I.B. Algas marinhas bentônicas dos recifes e ambientes adjacentes de Maracajaú, APA dos Recifes de Corais, RN, Brasil. Tese de Doutorado, Instituto de Botânica da Secretaria de Estado do Meio Ambiente. 2010.

SILVA, J.T.; BRAGA, T.M.P. Caracterização da Pesca na Comunidade de Surucuá (Resex Tapajós Arapiuns). Biota Amazônia, v. 6, p. 55-62, 2016.

SILVA, A.S.; FIGUERÊDO, J.G. A importância da espécie Mussismilia braziliensis para o Parque Nacional Marinho dos Abrolhos. Revista Brasileira de Educação Ambiental (RevBEA), v.15, n.1, p. 351-359. 2020.

SZMANT, A.M.; GASSMAN, N.J. The effects of prolonged bleaching on the tissue biomass and reproduction of the reef coral Montastrea annularis. Coral Reefs, v.8, n.4, p.217-224, 1990.

UFPE - Universidade Federal de Pernambuco. O mistério do peixe-leão: entenda os riscos do animal que pode ter chegado em Abrolhos. 2018. Disponível em: $<$ https://www3.ufpe.br/agencia/clipping/index.php?option=com_content\&view=article\&id= 35384\%3Avideo-com-suposto-flagra-provocou-polemica-entre-pesquisadores-e-orgaosambientais\&catid=371\%3Acorreio\&Itemid=1>. Acesso em: 15 de Out de 2019

VIANA, D.F. et al. Avaliação econômica da pesca do camarão sete-barbas, Xiphopenaeus kroyeri (HELLER, 1862), no município de Caravelas - Ba, Brasil. Boletim do Instituto de Pesca, São Paulo, v. 41, p. 419-428, 2015. 